\title{
УСЛОВИЯ ВНЕДРЕНИЯ ПЛЮРАЛИСТИЧЕСКОЙ МОДЕЛИ ГОСУДАРСТВЕННО-УПРАВЛЕНЧЕСКОЙ ДЕЯТЕЛЬНОСТИ В УКРАИНЕ
}

В статье рассмотрены существующие подходы к проблематике формирования и внедрения оценочных исследований государственно-управленческой деятельности, подчеркнута особая актуальность темы применения оценивания в Украине. Разработка концептуальных основ современной модели оценки государственно-управленческой деятельности, определенной нами как «плюралистическая», характеризуется высоким уровнем синтеза оценок, множественностью субъектов, объектов, задач, методов, инструментов и процедур оценки, а также широким назначением результатов оценивания, и позволяет получить комплексную оценку с учетом множества определенных критериев. Представленный подход возможен для внедрения только при наличии нескольких принципиальных условий. Нужна политическая воля по обеспечению надлежащего уровня открытости органов власти и их должностных лиц для процедур оценки. Также плюралистическая модель оценки предполагает наличие широкого круга субъектов оценки, готовых к сотрудничеству в рамках осуществления намеченных задач, обладающих соответствующими методами оценивания, а также необходимыми ресурсами. Кроме того, необходим общественный и внутрисистемный запрос на получение комплексной точной и объективной оценки государственно-управленческой деятельности.

Предложено разделение условий внедрения плюралистической модели оценивания государственно-управленческой деятельности на политические, организационные и научно-методологические, при наступлении которых оценивание приобретет черты непрерывности, системности и комплексности. Обзор политических (развитие политической культуры общества, наличие политической воли элит), организационных (новое место оценки в структуре принятия решений, наличие организационной структуры для оценивания) и научно-методических (разработка методик и стандартов оценки, наличие научно-консультативных центров) условий внедрения оценивания в их определенной взаимозависимости позволил автору сделать вывод о ведущей роли политических предпосылок, не умаляя значение других. Осуществление всех вышеуказанных условий, возможно, в разной мере, позволит внедрить плюралистическую модель оценивания государственно-управленческой деятельности для получения взвешенных, объективных, полных оценок от разных субъектов оценивания, базирующиеся на многих источниках исходной информации и альтернативных методиках определения индикаторов оценивания.

\footnotetext{
1 Лариса Лысакова - магистр государственного управления, заместитель начальника финансово-экономического отдела - зав.сектором бухгалтерского учёта и отчётности, Днепропетровский региональный институт государственного управления Национальной академии государственного управления при Президенте Украины; e-mail: larisa.lysakova@ gmail.com, 1.i.lysakova@vidr.dp.ua, почтовый адрес: Украина, 49044, г.Днепр, ул. Гоголя, 29, к. 207.
} 
Ключевые слова: оценивание государственно-управленческой деятельности, плюралистическая модель оценивания, внедрение оценивания государственно-управленческой деятельности, условия внедрения оценивания.

\section{1. ВВЕДЕНИЕ}

Повышение эффективности государственного управления в целом и/или в конкретных его отраслях всегда является неотложным заданием для любой страны. Рост эффективности государственного управления, как организующего влияния на общественные отношения и процессы, находится в зависимости от своевременного, объективного, действенного оценивания, «встроенного» в систему органов государственного управления и вне её.

Оценивание государственно-управленческой деятельности в Украине в настоящее время находится в начале формирования и, в основном, отвечает уровню развитию государственного управления, не способному обеспечить рост конкурентоспособности страны. Правительство определило необходимость изменений и положило начало реформе государственного управления, тем самым обеспечив первую общую предпосылку созданию и внедрению новой модели оценивания государственно-управленческой деятельности в стране. Следующим шагом в направлении реализации этой модели оценивания государственно-управленческой деятельности является создание условий, способных влиять, способствовать или прямо обеспечивать ее формирование и внедрение.

Анализ исследований и публикаций. Теоретическим основам оценивания государственного управления в целом и выделенным аспектам посвящено достаточно большое количество исследований зарубежных и украинских авторов. Однако вопрос условий формирования и внедрения оценивания государственноуправленческой деятельности больше интересует отечественных ученых, что объясняется необходимостью, во-первых, построения, а во-вторых, становление и усовершенствование системы оценивания в Украине. Значительный вклад в рассмотрение возможностей внедрения оценивания государственного управления в конкретных формах сделали М. Панченко ${ }^{2}$, О. Пархомчук ${ }^{3}$, Р. Рудницкая 4 , А. Чебан ${ }^{5}$, свое мнение относительно выработки критериев оценивания действен-

\footnotetext{
${ }^{2}$ М. Панченко, Методичні засади оцінки ефективності державного управління соиіальною сферою//Актуал. пробл. держ. упр.: зб. наук. пр. - О: ОРІДУ НАДУ, 2007. Вип. 1. С. 61-67.

${ }^{3}$ О. Пархомчук, Вимірювання результатів діяльності в суспільному управлінні: зарубіжний досвід//Актуал. пробл. держ. упр.: зб. наук. пр. - Д: ДФ УАДУ. - 2001. Вип. 1. 276 с. C. $147-152$.

${ }^{4}$ Р.М. Рудніцька, Необхідність розвитку аудиту ефективності в Україні та иляхи забезпечення його життєздатності//Реформування системи державного управління та державної служби: теорія і практика: матер. наук.-практ. конф. за міжнар. уч. (22 жовтня 2010 р.): у 2 ч. Ч. 1/за наук. ред. чл.-кор. НАН України В.С. Загорського, доц. А.В. Ліпенцева - Львів: ЛРІДУ НАДУ, 2010. С. 421-425.

5 O.І. Чебан, Концептуальні підходи до впровадження та інститучіоналізачії оцінювання в публічному управлінні// Актуальні пробл. держ. упр.: зб. наук. пр. ОРІДУ / [голов. ред. М.М.Іжа]. Вип. 3(63). - Одеса: ОРІДУ НАДУ, 2015, С. 212-217.
} 
ности государственного управления и местного самоуправления выразили И. Дегтярёва ${ }^{6}$, В. Дзюндзюк ${ }^{7}$, П. Надолишний ${ }^{8}$, М. Туленков ${ }^{9}$ и другие авторы.

Обзор соответствующих источников засвидетельствовал существование потребности дальнейшего развития исследования подходов к оцениванию государственно-управленческой деятельности в современных условиях общественных трансформаций в Украине. Поэтому цель нашего исследования будет заключаться в изучении условий формирования и внедрения плюралистичной модели оценивания государственно-управленческой деятельности в Украине, а также в выработке предложений относительно её полноценного дальнейшего функционирования.

\section{2. ОСНОВНАЯ ЧАСТЬ ИССЛЕДОВАНИЯ}

Вопрос оценивания государственно-управленческой деятельности в Украине в последнее время проявился чрезвычайно остро. Существующая система государственного управления признана малоэффективной, её преобразование является неотложной потребностью, удовлетворить которую должны конкретные шаги Стратегии реформирования государственного управления Украины на 2016-2020 годы. Она впервые предусматривает проведение полной и глубокой оценки состояния дел в системе государственного управления Украины в соответствии с «Принципами государственного управления», сформулированными SIGMA, а также других инструментов, с целью учёта исходного состояния государственного управления и возможного пересмотра реализации этой Стратегии ${ }^{10}$. Реализация мероприятий Стратегии, определенная в часовом измерении, будет способствовать одновременной и дальнейшей имплементации новой модели оценивания государственно-управленческой деятельности в Украине.

Мы рассматриваем эту модель как плюралистичную(от лат. Pluralis множественный), поскольку такая модель обеспечит высокий уровень синтеза и использования оценок благодаря применению множественного подхода во время определения субъектов, объектов, заданий, методов, критериев, инструментов и процедур оценивания. Основная идея концепции заключается в том, что современная модель оценки государственно-управленческой деятельности для того, чтобы соответствовать множеству вызовов внутреннего и внешнего сред национальной системы государственного управления, должна быть представлена как циклически структурированный ряд составляющих: «множество субъектов

${ }^{6}$ I.О. Дегтярьова, Концептуальні підходи до здійснення місиевого самоврядування та підвищення його ефективності в рамках забезпечення життєдіяльності людини/Актуальні пробл. держ. упр.: зб. наук. пр. - Х: Вид-во ХарРІ НАДУ, 2005. Вип. 1. С. 327-336.

7 В.Б. Дзюндзюк, Проблема визначення ефективності діяльності організацій публічного сектора//Актуальні пробл. держ. упр.: зб. наук. пр./редкол.: В. В. Корженко (голов. ред.) [та ін.]. Х: Вид-во ХарРІ НАДУ, 2002. Вип. 1. С. 7-11.

8 П.І. Надолішній, Ефективність державного управління та ії оцінювання: концептуальний niдxiд//Актуал. пробл. держ. упр.: зб. наук. пр. - О: ОРІДУ НАДУ, 2007. Вип. 4. С. 62-76.

9 М.В. Туленков, Теоретико-методологічні основи організаційної взаємодії в соиіальному управлінні: монографія. К: Каравела, 2009. 512 с.

10 Деякі питання реформування державного управління України: розпорядження Кабінету Міністрів України від 24 червня 2016 р. № 474-р.: [Електронний ресурс] / Режим доступу: www/zakon.rada.gov.ua. 
оценивания - множество объектов оценки - множество субъективных (отдельных) оценок - синтез комплексной оценки - множество реципиентов комплексной оценки - множество форм и способов использования комплексной оценки - множество влияний на объекты оценки». Данная разработка объединяет: имеющиеся и функционирующие в настоящее время элементы и предложенные нами новые элементы. Новым элементом, который предлагается нами для внедрения в действующую модель оценки государственно-управленческой деятельности в Украине является «блок синтеза комплексной оценки». Он сочетает процессы и процедуры: 1) формирование объединенных баз данных по полученным различными субъектами оценки отдельных оценок; 2) автоматическую обработку данных, что обеспечило бы их обобщение, систематизацию, хранение, а также доступ к ним заинтересованных лиц; 3) анализ и синтез, в результате чего представители государственного, общественного и частного секторов могли бы получить комплексную оценку государственно-управленческой деятельности в Украине в определенных временно-пространственных координатах. Исходным продуктом этого блока должна быть комплексная оценка, благодаря которой может сложиться максимально объективное представление о состоянии национальной системы государственного управления, ее подсистем и элементов, их функционирования и перспективы развития. Внедрение этой модели может стать реальным лишь при определенных условиях, выявление и рассмотрение которых позволит выработать необходимые механизмы внедрения оценивания государственного управления.

Анализ таких условий относительно внедрения разных других видов оценивания уже осуществлялось учёными. В частности, Р. Рудницкая приходит к выводу, что факторами внедрения и успешной реализации аудита эффективности в Украине являются:

1. Политическая поддержка, соответствующие законы, преданное руководство.

2. Законодательное закрепление функциональных предпосылок (мандат на осуществление, свобода в выборе, возможность делать выводы и отчитываться, свобода размещения результатов, доступ ко всей необходимой информации, свобода в отборе персонала).

3. Формирование стратегий для общения со СМИ, объектами аудита, гражданами.

4. Установление сетей с учёными, неправительственными организациями.

5. Подбор компетентного персонала и привлечения компетентного руководителя со знанием выполняемой работы.

6. Развитие мощностей для методологического, аналитического и профессионального обучения.

7. Установление предпосылок, стандартов и наставлений для гарантирования качества подготовки отчетов.

8. Подготовка интересных, провоцирующих, обоснованных и направленных на читателя отчетов ${ }^{11}$.

11 Р.М. Рудніцька, Необхідність розвитку аудиту ефективності в Украӥні та иляхи забезпечення його життєздатності//Реформування системи державного управління та державної служби: теорія і практика: матер. наук.-практ. конф. за міжнар. уч. (22 жовтня 
Эти факторы также являются политическими и организационными условиями. Таким образом, вопрос оценивания государственного управления пройдет этапы сначала политических решений, а потом действий. Подобный вывод можно сделать и с того, какие два важных механизма: политический и организационный, Б. Хэд называет способными подорвать потенциал связи информации и выработки политики, поэтому, обратно, можно говорить об их роли в запуске системы оценивания ${ }^{12}$.

М. Панченко предлагает исходить из сознательных ограничений, соблюдение которых предоставит возможность построить действенную систему оценивания, способной выполнять функции обратной связи:

- ограничение объектов оценивания лишь теми институтами, которые имеют непосредственное влияние на эту сферу;

- ограничение системы оценивания лишь задокументированной информацией, которая при условиях невозможности проверки будет считаться объективной;

- ограничение при анализе рассмотрением основных элементов и процедур системы государственного управления;

- ограничение на первом этапе разработки и внедрения методики оценкой не реальных результатов деятельности государственного управления, а результатов создания в органах государственного управления эффективных условий для обеспечения эффективного управления.

Наиболее пригодным индикатором качества государственного управления с этой точки зрения будет степень внедрения и использования эффективных технологий государственного управления ${ }^{13}$.

О. Пархомчук пишет, что желаемыми предпосылками для системы измерения результатов деятельности в общественном управлении являются:

- подержка усилий на высшем уровне управления;

- относительная стабильность деятельности. Те программы, которые находятся в процессе изменения, не являются лучшими вариантами для имплементации системы измерения результатов;

- электронная обработка информации ${ }^{14}$.

И. Дегтярёва предлагает такие критерии оценивания эффективности местного самоуправления ${ }^{15}$ : степень использования потенциальных возможностей в реализации определенных законодательством полномочий; степень соответствия организационной структуры и численности работников целям и заданиям органа;

2010 р.): у 2 ч. Ч. 1/за наук. ред. чл.-кор. НАН України В. С. Загорського, доц. А.В. Ліпенцева. - Львів: ЛРІДУ НАДУ, 2010, с. 424.

12 B.W. Head, Toward more "evidence-informed" policy making? / Public Administration Review Volume 76, Issue 3, May 2016 Pages 472-484.

${ }_{13}$ М. Панченко, Методичні засади очінки ефективності державного управління сочіальною сферою//Актуал. пробл. держ. упр.: зб. наук. пр. - О: ОРІДУ НАДУ, 2007. Вип. 1, с. 64-65.

14 О. Пархомчук, Вимірювання результатів діяльності в суспільному управлінні: зарубіжний досвід//Актуал. пробл. держ. упр.: зб. наук. пр. - Д: ДФ УАДУ. - 2001. Вип. 1, с. 149.

15 I.O. Дегтярьова, Конщептуальні підходи до здійснення місиевого самоврядування та підвищення його ефективності в рамках забезпечення життєдіяльності людини//Актуальні пробл. держ. упр.: зб. наук. пр. - Х: Вид-во ХарРІ НАДУ, 2005. Вип. 1. с. 334. 
соответствие деятельности органов местного самоуправления потребностям и интересам местного населения; качество оказанных услуг населению; наличие обратной связи органов местного самоуправления с населением; уровень достижения целей в развитии соответствующей территории и т.п. Говорит о многокритериальном подходе к оценке и одновременно обобщает критерии оценивания деятельности органов самоуправления до двух - экономического и социального, считая важнейшим последний критерий.

П. Надолишний также утверждает, что эффективность государственного управления имеет два параметра, социальный и экономический, однако не только не выделяет главного среди них, но и называет их двумя сторонами единого целого ${ }^{16}$. Похожее с И. Дегтярёвой мнение поддерживает М. Туленков, который называет общими критериями эффективности развития социальных систем социальный, экономический и политический, указывает на их тесную взаимосвязь, и важнейшую роль отводит критерию социальной эффективности как обобщающему и конечному ${ }^{17}$. Аналогично Б. Гаврилишин во время исследования эффективности функционирования государства как возможности удовлетворения основных потребностей человека предлагает проводить оценку эффективности по показателям, объединенным в три группы: экономические, социальные и политические ${ }^{18}$.

Считаем, оценивание управленческой деятельности органов власти не может быть ограниченным социальными и экономическими критериями. Политическая составляющая государственного управления возникает из его природы и является самостоятельной единицей, подлежащей оценке, например, к политическому критерию оценивания можно отнести показатель положения государства на международной арене. Так, М. Хольцер предлагает пять оценочных, измерительных элементов: информационный, социальный, технологический, управленческий и политический ${ }^{19}$. В. Дзюндзюк дискутирует с этим мнением и аргументирует необходимость исключения политического элемента, считая его скорее постоянно присутствующим фактором внешней среды ${ }^{20}$.

А. Чебан, цитируя М. Бамбергера, определяет, что институционализация системы оценивания происходит, когда 1) процесс оценивания начинается на национальном уровне, 2) существует сильная взаимосвязь с ключевыми заинтересованными сторонами в процессе оценивания, 3) есть четко определенные процедуры и методологии, 4) система оценивания интегрирована в отраслевые и национальную системы мониторинга и оценивания, которые генерируют большую часть данных, используемых в соответсвующих исследованиях, 5) оце-

16 П.І. Надолішній, Ефективність державного управління та ї̈ оцінювання: концептуальний niдxiд//Актуал. пробл. держ. упр.: зб. наук. пр. - О: ОРІДУ НАДУ, 2007. Вип. 4, с. 73.

17 М.В. Туленков, Теоретико-методологічні основи організаційної взаємодї в соціальному управлінні: монографія. К: Каравела, 2009, с. 413.

18 I. Дутка, Спосіб оцінки ефективності функціонування держави із забезпечення громадян України житлом через призму побудови громадянського суспільства// Ефективність держ. упр.: зб. наук. пр. ЛРІДУ НАДУ. -Вип. 10. - Львів : ЛРІДУ НАДУ, 2006, с. 75.

19 В.Б. Дзюндзюк, Проблема визначення ефективності діяльності організаиій публічного сектора//Актуальні пробл. держ. упр.: зб. наук. пр./редкол.: В. В. Корженко (голов. ред.) [та ін.]. Х: Вид-во ХарРІ НАДУ, 2002. Вип. 1, с. 7.

20 Ibidem, c. 8. 
нивание интегрировано в национальную систему формирования бюджета и планирования развития, 6) основное внимание уделяется развитию потенциала в сфере оценивания ${ }^{21}$.

Таким образом, на основании осуществлённого анализа условиями для внедрения новой модели оценивания государственно-управленческой деятельности считаем такие.

Политические условия:

- развитие политической культуры общества, которое обусловливает общественный запрос на получение регулярных, оперативных, научно обоснованных объективных (сбалансированных) оценок государственно-управленческой деятельности в Украине;

- наличие политической воли элит относительно внедрения новой системы оценивания государственно-управленческой деятельности как обязательного элемента принятия управленческих решений.

Реализация политических условий будет основой для удовлетворения организационных условий.

Организационные условия:

- новое место оценивания в структуре принятия решений: на всех уровнях управления решения должны приниматься с опорой на полученные комплексные оценки, а не субъективно, также в качестве важной характеристики выступает возможность поступления информации из альтернативных источников (получатели, поставщики услуг, общественное мнение, служба статистики, эксперты);

- наличие организационной структуры для оценивания: организационнотехнологическое обеспечение синтеза оценки с одновременным усилением институционной возможности неправительственных организаций и других субъектов оценивания государственно-управленческой деятельности.

Научно-методические условия:

- разработка собственных методик и стандартов оценивания, тем больше, что существует примеры действенных национальных оценок качества государственного управления, которые могут лечь в основу разработки как итоговых индексов, так и способов анализа и оценивания государственно-управленческой деятельности;

- наличие научно-консультативных центров оценивания, причём не в организационном аспекте вопроса, а в понимании формирования «научных школ» оценивания государственно-управленческой деятельности.

При таких условиях оценивание государственно-управленческой деятельности перестанет иметь ситуативный характер, приобретет черты системности и комплексности. Рассмотрим детальнее каждую из условий через призму ее возможного влияния на процессы имплементации плюралистичной модели оценивания.

Важность роли развития политической культуры общества как предпосылки внедрения новой модели оценивания государственно-управленческой деятельности заключается в его двойственности. Ведь высокий уровень политической культуры

21 O.I. Чебан, Концептуальні підходи до впровадження та інституціоналізачії оцінювання в публічному управлінні// Актуальні пробл. держ. упр.: зб. наук. пр. ОРІДУ / [голов. ред. М.М.Іжа]. Вип. 3(63). - Одеса : ОРІДУ НАДУ, 2015, с. 213. 
граждан не только сформирует запрос и будет способствовать построению модели оценивания государственно-управленческой деятельности, но и станет её важной составляющей. В свою очередь, воплощение предложенной модели оценивания государственно-управленческой деятельности тоже будет способствовать росту уровня политической культуры общества. Использование общественного воздействия как индикатора развития политической культуры общества отвечает основополагающим принципам административного управления в ЕС: открытости, участию, подотчетности, эффективности и слаженности, и обусловлено тем, что новый взгляд на государственно-управленческую деятельность сфокусирован на снижении барьеров в отношениях между обществом и властью. В развитых странах отношения с гражданами укрепляются с целями: улучшения качества политики за счет возможности использования широкого круга источников информации, мыслей и потенциальных решений; обеспечения соответствия вызовам развития информационного общества; интеграции взноса граждан в процесс формирования политики; предоставления ответу на призывы о повышении прозрачности и подотчетности деятельности органов власти; укрепление доверия общественности к органам власти $^{22}$. Общество как источник публичной власти, как налогоплательщик хочет, чтобы государственно-управленческие услуги отвечали его потребностям и были качественными. Это рождает новые формы сотрудничества, для общего управления общественными делами и оценивания их результатов существуют специальные механизмы, среди которых - общественная экспертиза. Общественная экспертиза деятельности органов исполнительной власти, суть и характеристики которой изложены в постановлении Кабинета Министров Украины 2008 года со следующими изменениями «Об утверждении Порядка содействия проведению общественной экспертизы деятельности органов исполнительной власти» ${ }^{23}$, является составляющей механизма демократического управления государством, способствует сотрудничеству органов власти и общественности и входит в систему оценивания государственно-управленческой деятельности.

Среди перспективных направлений проведения экспертиз в органах исполнительной власти учёные определяют следующие:

- аудит административной деятельности,

- определение желательных для объектов управления результатов деятельности,

- оценивание работы государственных служащих,

- оптимизация процесса генерирования альтернативных вариантов решений,

- определение рейтингов инвестиционных проектов,

- прогнозирование основных направлений развития региона ${ }^{24}$.

В Украине из отмеченного на практике чаще всего прибегают к оцениванию работы государственных служащих, рейтингу социально-экономического состояния

22 Залучення громадян до розробки політики: інформація, консультації та участь громадськості - Policy Brief. - жовтень 2007, с. 2.

${ }^{23}$ Про затвердження Порядку сприяння проведенню громадської експертизи діяльності органів виконавчої влади: постанова Кабінету Міністрів України від 5 листопада 2008 р. № 976: [Електронний ресурс] / Режим доступу: www/zakon.rada.gov.ua

${ }^{24}$ Методологія експертного оцінювання: конспект лекцій/Уклад.: В.П. Новосад, Р.Г. Селіверстов. К: НАДУ, 2008, с. 29. 
развития регионов, частично - к усовершенствованию генерирования альтернативных вариантов решений. Современной тенденцией в оценивании государственно-управленческой деятельности является поиск наибольшего количества способов обнародования результатов процесса оценивания и использования разных инструментов привлечения общественности, в том числе общественной экспертизы, к этому процессу ${ }^{25}$.

Кроме общественной экспертизы, формами общественного воздействия на формирование государственно-управленческих решений являются консультативно-согласовательные органы (общественные советы), общественный контроль, лоббирование ${ }^{26}$. 2010 годом датировано действующее постановление Кабинета Министров Украины «Об обеспечении участия общественности в формировании и реализации государственной политики» ${ }^{27}$, являющееся нормативно-правовой основой проведения консультаций с общественностью. Таким образом, на сегодня в Украине сложилась ситуация, когда институционная способность гражданского общества располагает достаточной правовой институализацией одновременно с организационной слабостью институтов гражданского общества, обусловленной рядом объективных и субъективных факторов ${ }^{28}$. Можно сказать, что наряду с содействием оцениванию, и стало быть, повышению эффективности государственно-управленческой деятельности, общественное воздействие служит цели укрепления доверия общества к органам власти, такое сопровождение деятельности органов исполнительной власти способствует утверждению демократии в управлении, в частности принципов прозрачности и коллегиальности в осуществлении властных полномочий. Развитие политической культуры в целом сможет сыграть решающую роль в выработке и становлении комплексной системы оценивания в государственном управлении.

Следующее условие «политического» блока, а именно, наличие политической воли элит относительно внедрения новой системы оценивания, хотя и выделенная нами отдельно, тесно связана с предыдущей. И общество, и его политическая элита выступают в качестве заказчиков оценивания государственно-управленческой деятельности, прямо или опосредствовано могут быть задействованы в процессе оценивания, но особенность фактора политической элиты в том, что деятельность политических деятелей одновременно подпадает под оценивание.

25 Моніторинг та оцінювання стратегій і програм регіонального розвитку в Україні / Лендьел М., Винницький Б., Ратейчак Ю., К: В-во «К.І.С.»-2007, с. 32.

${ }^{26}$ О. Антонова, В. Климович, Е. Самбук, Инструменты гражданского воздействия на развитие публичной службы в Украине как фактор гуманизации украинского общества, „Modern Management Review” 23/1 (2016), c. 17.

27 Про забезпечення участі громадськості у формуванні та реалізації державної політики: постанова Кабінету Міністрів України від 3 листопада 2010 р. № 996: [Електронний ресурс] / Режим доступу: www/zakon.rada.gov.ua

${ }_{28}^{28}$ М. Стасишин, Інституціийна спроможність громадянського суспільства в прочесі прийняття управлінських рішень//Актуальні проблеми державного управління: зб. наук. пр. ОРІДУ / [голов. ред. М.М.Іжа]. Вип. 1(69) - Одеса: ОРІДУ НАДУ, 2017, с.133; см. также: С. Олефіров, Нормативно-правове забезпечення держсавно-громадської взаємодї в Україні//Актуальні проблеми державного управління : зб. наук. пр. ОРІДУ / [голов. ред. М.М.Іжа]. Вип. 2(70) - Одеса: ОРІДУ НАДУ, 2017, с. 75-79. 
Развитие политической культуры общества, потребность в дальнейшей демократизации, усиление борьбы с коррупцией будут изменять образ политической элиты страны. Народ - единственный субъект и источник государственной власти, поэтому политические деятели с властными полномочиями должны удовлетворять требования граждан, общества, если возможно, предшествовать им. Подтверждает наше мнение В. Малюська, которая считает: «возможности политики определяются и подкрепляются особенной морально-этической ответственностью элит перед обществом в целом или его отдельными группами, что чаще всего превышает возможности их служебно-функциональной ответственности и служит более существенной опорой власти, чем ее формальная подмога» ${ }^{29}$.

Подобно, если развитие политической культуры порождает осознание гражданами своей ответственности за состояние дел в государстве, то наличие соответствующей политической воли руководителей станет залогом осознания необходимости существования оценивания как неотъемлемой составной системы государственного управления. Придёт понимание и применение оценивания эффективности государственно-управленческих решений преимущественно в качестве предупреждения, позитивного, а не карательного метода, имеющего целью ликвидировать проблемные аспекты, сделать государственное управление направленным на удовлетворение потребностей общества при справедливом наборе санкций. Кроме того, ответственные за принятие решений заинтересованы в том, чтобы базировать свои решения на результатах своевременного и объективного оценивания, то есть достоверных данных, ведь когда реформы делаются без обоснования их полезности и эффективности, изменения принимают фрагментарный, иногда антисоциальный характер, и не достигают своей цели. Сначала принимается решение о необходимости преобразований, потом осуществляется нормативно-законодательное основание, они начинают воплощаться, как следствие - недостаточная поддержка со стороны общества и недостижения заявленных целей. На сегодня среди национальных приоритетов - борьба с коррупцией, модернизация армии, реформа здравоохранения, рост ВВП и другие, и реализация этих мега-проектов будет сверхтяжелым заданием без применения их системного оценивания. Ведь оценивание способно обеспечить ряд значимых управленческих потребностей лиц, которые принимают и осуществляют выполнение государственных решений и программ: в информации, в отчетности, в управленческом совете, в учёбе и совершенствовании ${ }^{30}$.

Интеграция модели оценивания в украинское государственное управление процесс непростой, а при отсутствии политической воли мало возможный. Опасностью на пути внедрения модели оценивания может стать формальный подход со стороны политического руководства. Недаром М. Вебер выделял следующие три основных качества политического деятеля: страсть (направленность на саму суть дела), чувство ответственности и глазомер (возможность отдаться

29 В.А. Малюська, Ціннісні аспекти державного управління в Украӥні//Держава та регіони (Серія: Держ. упр.). 2010. № 4. с. 19.

30 С.Г. Туронок, Оченка государственной политики и задачи реформ: уроки зарубежного опыта / Режим доступа: www.spa.msu.ru/images/File/Vestnik/Turunok.pdf. - Название с экрана. 
влиянию реальностей $)^{31}$. Согласимся, что эти качества, подкрепленные честностью, будут способствовать, и, возможно, станут залогом запуска полноценного оценивания государственно-управленческой деятельности, когда политическая элита будет осознавать не только необходимость в оценивании, например, для получения определенной информационной базы, но и возможность оценивания ее решений и действий с не всегда приятными выводами о соответствии её деятельности надеждам общества. То есть наличие политической воли элиты становится важным условием воплощения всестороннего оценивания государственно-управленческой деятельности, ведь это приведет к оформлению её самой в качестве объекта оценивания. Из этого исходит следующая особенность роли элиты государственного управления в оценивании, которое не ограничивается потребностью в определенной информации и содействии имплементации модели оценивания государственно-управленческой деятельности, а также предусматривает встраивание в технологию формирования и реализации решений элемента самооценивания, тем больше, что эффективность управления отождествляют с эффективностью руководства. Ещё одна сторона воли политической элиты во внедрении оценивания государственно-управленческой деятельности заключается в ответственности элиты и за востребованность оценивания, и за использование рекомендаций, потому что усилия по формированию модели оценивания считаем только первым шагом, его всесторонняя поддержка - следующие шаги, а завершающий - неотвратимость реакции по результатам оценивания, не обязательно наказание или награда, но концентрация внимания и исправление ситуации или поддержка в случае необходимости.

Подтверждением необходимости уделить отдельное внимание условию политической воли элит опосредованно служит и тот факт, что оценивающие исследования в США, как правило, инициируются именно высшим руководящим звеном организаций. Именно эти инициативы обусловили постепенный рост внутренних оценивающих исследований в абсолютном выражении и в пропорции к общему объему исследований с одновременным завершением процесса институциализации оценивания государственной политики и программ как неотъемлемого компонента теории и практики современного государственного управления ${ }^{32}$.

Много трудов посвящено теме лидерства, роли личностей в истории человечества. И в данном конкретном вопросе внедрения устойчивой модели оценивания государственно-управленческой деятельности в Украине позиция элиты должна быть чувствительной к настроениям общества и в то же время сознательной и решительной. Принимая во внимание то, что внедрение оценивания является достаточно сложным и не мгновенным процессом, от политической воли элит будет зависеть преемственность, последовательность шагов. Умение признать и развить достижение предыдущей власти, возможно, противоположных или, по крайней мере, неодинаковых политических взглядов, будет способствовать непрерывности воплощения модели оценивания, следовательно, успеху в создании полноценного системного оценивания.

${ }^{31}$ В.А. Малюська, Ціннісні аспекти..., с. 18.

${ }^{32}$ С.Г. Туронок, Оиенка государственной политики... 
Одним из организационных условий возможности внедрении оценивания государственно-управленческой деятельности мы назвали новое место оценивания в структуре принятия решений. Отметим, что во время формирования модели оценивания государственно-управленческой деятельности преимуществом будем наделять понимание оценивания как средства предупреждения в противовес реакции на существующее положение любой сферы. Для запуска предложенной модели оценивания необходимо создать нормативно-правовую базу оценивания деятельности органов государственной власти, разработать методики и процедуры оценивания и методы принятия решений, установить четкие стандарты обследования, определить потребность в ресурсах, например, финансирования оценивающих исследований в мировой практике складывает 2-7\% бюджета социальных программ $^{33}$, что надо учитывать при планировании. Нужно обеспечить выполнение оценивания на всех этапах «жизненного цикла» программ, проектов, деятельности органов государственной власти, осуществления профессиональных обязанностей государственными служащими, и подчёркивая весомость заключительного оценивания, всё-таки уделять внимание оцениванию на первых стадиях, так как тогда остаётся возможность привнесения кардинальных или незначительных, однако необходимых изменений. Поэтому внедрение модели оценивания государственноуправленческой деятельности в качестве отдельного условия требует органичного встраивания оценивания в технологию формирования и реализации управленческих решений. Оценивание государственно-управленческой деятельности должно стать постоянной, желательно непрерывной, сопровождающей составляющей разработки плана действий, подготовки решений и их практической реализации, потому повышаются требования к качеству самого оценивания. Усовершенствование его средств и критериев должно быть адекватным ответом на изменения объектов оценивания.

Отдельной организационной структуры лишь для оценивания государственноуправленческой деятельности в Украине не существует. Как упоминалось выше, запланированная первая за годы независимости оценка состояния государственного управления как один из приоритетов Стратегии реформирования государственного управления Украины на 2016-2020 годы в качестве ответственных за выполнение называет Вице-премьер-министра по вопросам европейской и евроатлантической интеграции Украины, Секретариат Кабинета Министров Украины, Национальное агентство Украины по вопросам государственной службы, Министерство экономического развития и торговли, Министерство финансов, за мероприятия по реализации этой Стратегии - Министра Кабинета Министров Украины, Национальное агентство Украины по вопросам государственной службы, Министерство финансов, Министерство экономического развития и торговли, Секретариат Кабинета Министров Украины. Документ предусматривает создание ведущего структурного подразделения по вопросам реформирования государственного управления в составе Секретариата Кабинета Министров Украины со штатной численностью от 10 до 20 государственных служащих с соответствующим уровнем профессиональной компетентности. И поскольку Национальное агентство Украины

${ }^{33}$ И.В. Крапива, Оченочные исследования: сложности внедрения и проблемы применения в социологии//Вісник Харківського національного університету імені В.Н. Каразіна. 2010. № 889 , c. 67 . 
по вопросам государственной службы, Министерство финансов будут координировать направление государственной службы и управления человеческими ресурсами, Министерство экономического развития и торговли - направления административных процедур и предоставления административных услуг, а также электронного управления, Секретариат Кабинета Министров Украины, а именно вновь созданное подразделение, определено координатором реформирования государственного управления в целом, привлечённым к стратегическому планированию, формированию и координации государственной политики, организации системы центральных органов исполнительной власти. Согласно этому распределению направлений реформы можно допустить, что это структурное подразделение среди других будет «ответственным исполнителем» начального анализа состояния системы государственного управления, затем - разработки и согласования с экспертами SIGMA методики проведения оценки государственного управления в Украине, непосредственно следующего проведения оценки, и, наконец, аналитического отчёта о результатах оценки состояния государственного управления, в случае необходимости, с предложениями по внесению изменений в указанную Стратегию. Считаем, что такое структурное подразделение и в дальнейшем - после воплощения Стратегии - сможет быть определено аналитической службой оценивания государственно-управленческой деятельности в Украине.

Что касается зарубежного опыта оценивания управления состоянием административной системы, в качестве субъектов оценивания эффективности государственного управления могут выступать очень разные варианты организации оценки. На международном уровне получили признание индексы (GRICS, конкурентоспособности роста, восприятия коррупции, экономической свободы и т.п.), базирующиеся на экспертных оценках и опросах компетентных групп. В США в числе прочего организовано оценивание государственного управления по выявлению «лучшей практики», изучение условий обеспечения качества исполнительной власти как некоммерческий проект, профинансированный донорскими учреждениями. В Бельгии оцениванием бюрократической составляющей административных услуг и законодательных актов занимается государственный секретариат по административному упрощению. В Швеции Национальное финансовое управление составляет рейтинг качества финансового управления органов исполнительной власти (анализу подлежат финансовые процедуры и административные процессы).

Среди научно-методических предпосылок мы выделили существование и развитие собственных методик и стандартов оценивания разных аспектов и уровней государственно-управленческой деятельности, которые смогут учесть определённые потребности и особенности начала системного оценивания государственного управления в Украине, или базируясь на лучшем мировом опыте, или стать проявлением «нового слова» в оценивании. Методология оценивания эффективности государственного управления находится в постоянном развитии, нуждаются в решении такие проблемы: трудности в определении целей и в их отражении в операционных и измеримых индикаторах; сложности в получении достоверных эмпирических данных для описания показателей; ошибочность прогнозирования побочных эффектов и неумышленных последствий; трудоёмкие 
методы опытов редко применимы ${ }^{34}$. Кроме этих, есть мнения о значительном несовершенстве определения многих рейтинговых индексов стран в силу общей ориентированности измерения на США как эталон или формирования критериев, систем сбора и анализа данных и тому подобное, рассчитанного на задействования, в первую очередь, для развитых стран. Также исследователи указывают и на другие недостатки имеющихся методик, тем самым предлагая пути усовершенствования, в том числе актуализации, методологического базиса оценивания государственноуправленческой или другой деятельности и поощряя других к их поиску. Так, невзирая на общепринятые показатели экономической эффективности предприятий, почти половина больших европейских компаний имеют собственные внутренние системы оценивания эффективности на основе финансовых показателей. Поэтому на практике применяют много методов оценивания, которые дают противоречивые результаты. Таким образом, потребность в разработке методологических основ оценивания государственно-управленческой деятельности обусловлена попытками, во-первых, минимизировать влияние недостатков на полноту информации, вовторых, учесть особенности и отличия построения государственного управления в каждой стране. Роль наработанного опыта развитых государств в сфере этой является очень важной. Например, исходя из фактической унитарности нашего государства, во время дискуссии относительно развития действенной модели оценивания мы склоняемся к унифицированной системе оценки эффективности государственно-управленческой деятельности против оригинальной, введенной в США, ведь отдельные штаты являются несравненно самостоятельными относительно регионов (областей) Украины, потому в дальнейшем возникнет потребность в единых методиках оценивающих исследований с учетом отличий общегосударственного и локального уровней. На данный момент констатируем, что несмотря на существование многих методологических подходов к оценке, методологическая база несформирована, комплексная методика основательной исчерпывающей оценки оценки эффективности публичного управления отсутствует ${ }^{35}$.

Следующим условием мы назвали наличие научно-консультативных центров оценивания государственно-управленческой деятельности, что, с одной стороны, среди прочего будет обеспечивать выполнение предварительного условия развитие методологических основ, а с другой, будет следствием формирования политических условий, то есть появление таких научно-консультативных центров, особенно независимых, станет ответом на запрос государства и общества. Такие учреждения в качестве внешних субъектов оценивания государственно-управленческой деятельности могут быть разнообразными: государственными и негосударственными; теми, которые занимаются методологическими вопросами оценивания, которые занимаются проведениям оценивания, которые занимаются и тем, и вторым; такими, которые специализируются на отдельных объектах или видах оценивания, и универсальными и т.п. К тому же, развитие научно-консультативных центров, в том числе по оцениванию государственно-управленческой деятельности,

34 О.А. Линдюк, Модель очінювання ефективності модернізації державної служби/l Аспекти публічного управління: електрон. наук. фахове вид. 2016. № 8.

35 О.А. Таньчук, Основні підходи до оџінювання ефективності публічного управління//Вісник Національної академії державного управління при Президентові України. 2015. № 3(78), c. 69 . 
будет способствовать дальнейшему распространению такой формы сотрудничества, как аутсорсинг, так как оценивание является очень благоприятным для привлечения внешних относительно организации специалистов (обычно экспертов) сферой. Причём научно-консультативные центры оценивания смогут использовать преимущества разных схем аутсорсинга и для внутреннего, и для внешнего оценивания государственно-управленческой деятельности, когда в роли заказчика выступают или органы государственной власти, или общественно-социальные институты. Общими же способами проведения оценивания являются: привлечение к роботе эксперта как штатного сотрудника; обращение к сторонней организации; объявление конкурса на проведение оценивания с помощью конкурсной процедуры; проведение оценивания ученым-исследователем из академической среды (как подтверждение теории на практике $)^{36}$.

Что касается рассмотренного условия, можем констатировать, что спрос на научно-консультативные центры оценивания, пока небольшой, существует и будет расти. На сегодня недостаёт программ и курсов, посвящённых подготовке специалистов по оцениванию государственно-управленческой деятельности. В то время как система высшего образования Европы и Америки предлагает широкий спектр подобных программ, которые формируют как теоретические знания, так и практические навыки проведения оценочных исследований, что позволяет гарантировать профессионализм специалистов в сфере оценки ${ }^{37}$. Источниками экспертных знаний в этой отрасли являются частные корпорации, университетские научно-исследовательские центры, некоммерческие организации, профессиональные ассоциации.

Достаточная степень обеспечения развития научно-методической мысли в оценивании государственно-управленческой деятельности, вовсе не будучи первичным условием ввода оценивания, является необходимой. Например, после нескольких десятилетий формального мониторинга и оценивания, как пишет Д. Кэмерон, в 1990-е оценивание столкнулось, в том числе, с проблемой получения информации из-за сомнений относительно точности выходных данных, их обработки и анализа ${ }^{38}$. Ответ тогда был найден в широком использовании методов исследования рынка, абстрактных выводов из информационной экономики, выборочного метода статистической теории и т.п., смешанных с практическим опытом.

Таким образом, на основе рассмотренных политических (развитие политической культуры общества, наличие политической воли элит), организационных (новое место оценивания в структуре принятия решений, наличие организационной структуры для оценивания) и научно-методических условий (разработка методик и стандартов оценивания, наличие научно-консультативных центров) внедрения оценивания государственно-управленческой деятельности главную роль отдаём политическим. Во-первых, надлежащую степень развития факторов из числа политических условий можно назвать первым этапом имплементации оценивания в повседневность государственно-управленческой деятельности, на базе и при

36 Державна політика: підручник / Нац. акад. держ. упр. при Президентові України; ред. кол.: Ю.В. Ковбасюк, К.О. Ващенко, Ю.П. Сурмін [та ін.]. - Київ: НАДУ, 2014, с. 105.

37 И.В. Крапива Оценочные исследования..., с. 67.

38 J. Cameron, The challenges for monitoring and evaluation in the 1990s - Project Appraisal 8(2) - June 1993 - Taylor \& Francis Pages 91-96. 
содействии которого сможет состояться следующий или одновременный шаг реализация организационных условий. Именно политические условия «отвечают» за спрос на оценивающие исследования. Во-вторых, организационные условия по сравнению с политическими являются, можно сказать, зависимыми, управляемыми, то есть «субъектными» относительно политических, их легче видоизменять, и в отличие от них неблагоприятные политические условия тяжелее преодолеть. Лучшее развитие политических условий является условно возможной ситуацией, обратные же обстоятельства, а именно существование выстроенной организации оценивания при «прохладном» формальном отношении к нему не будет достигать цели оценивания, то есть повышать качество и ответственность в сфере государственно-управленческой деятельности, потому что осуществленное оценивающее исследование не гарантирует свою практическую роль, не защищает от принятия популистских решений и тому подобное. Что касается научно-методических условий, они являются относительно «независимыми», однако должны соответствовать целям и задачам оценивания, которые в целом определяются политическими и организационными условиями. Поэтому, по нашему мнению, хотя влияние политических условий на возможность внедрения оценивания значительно превышает степень влияния организационных условий, состояние их развития нельзя игнорировать Не менее важными являются научно-методические условия, ведь они позволяют получить взвешенные, объективные, полные оценки от разных субъектов оценивания, которые базируются на многих источниках исходной информации и альтернативных методиках определения индикаторов оценивания государственно-управленческой деятельности. Вместе с организационными научно-методические условия обеспечивают предложение знаний по оцениванию государственного управления.

\section{3. ВЫВОДЫ}

Оценивание государственного управления - управленческая функция, назначение которой заключается в повышении его эффективности. Оценивание способно дать ответы на вопрос необходимости реформирования или внесения изменений в сфере государственно-управленческой деятельности, а также проанализировать их ход и результаты, стать основой для предложений относительно улучшения текущего состояния и т.п. Внедрение действенной плюралистичной модели оценивания государственно-управленческой деятельности в Украине зависит от групп политических, организационных и научно-методических условий, базовыми из которых мы определили развитие политической культуры общества и наличие политической воли элит. Считаем, впервые условия формирования и внедрения оценивания государственного управления в нашей стране могут обеспечить становления плюралистичной модели оценивания. Таким образом, для внедрения новой модели оценивания государственно-управленческой деятельности в Украине на достаточном уровне должны быть обеспечены политические, организационные и научно-методические условия во взаимосвязи культуры политики, практики и исследований. 


\section{ЛИТЕРАТУРА}

[1] Антонова О., Климович В., Самбук Е., Инструменты гражданского воздействия на развитие публичной службы в Украине как фактор гуманизации украинского общества, „Modern Management Review” 23/1 (2016), c. 7-29.

[2] Дегтярьова I.О., Кониептуальні підходи до здійснення місиевого самоврядування та підвищення його ефективності в рамках забезпечення життєдіяльності людини//Актуальні пробл. держ. упр.: зб. наук. пр. - Х: Вид-во ХарРІ НАДУ, 2005. Вип. 1. С. 327-336.

[3] Державна політика: підручник / Нац. акад. держ. упр. при Президентові України; ред. кол. : Ю.В. Ковбасюк, К.О. Ващенко, Ю.П. Сурмін [та ін.] - Київ : НАДУ, 2014, 652 c.

[4] Деякі питання реформування державного управління України: розпорядження Кабінету Міністрів України від 24 червня 2016 р. № 474-р.: [Електронний ресурс] / Режим доступу: www/zakon.rada.gov.ua

[5] Дзюндзюк В.Б., Проблема визначення ефективності діяльності організацій публічного сектора//Актуальні пробл. держ. упр.: зб. наук. пр./редкол.: В.В. Корженко (голов. ред.) [та ін.]. Х: Вид-во ХарРІ НАДУ, 2002. Вип. 1. С. 7-11.

[6] Дутка I., Спосіб оцінки ефективності функціонування держави із забезпечення громадян України житлом через призму побудови громадянського суспільства/ Ефективність держ. упр.: зб. наук. пр. ЛРІДУ НАДУ. -Вип. 10. - Львів: ЛРІДУ НАДУ, 2006 - С. $74-80$.

[7] Залучення громадян до розробки політики: інформачія, консультаиії та участь громадськості - Policy Brief. - жовтень 2007 - 8 с.

[8] Крапива И.В,. Оченочные исследования: сложности внедрения и проблемы применения в социологии//Вісник Харківського національного університету імені В.Н. Каразіна. 2010. № 889. С. 65-68.

[9] Линдюк О.А., Модель оцінювання ефективності модернізації державної служби/। Аспекти публічного управління: електрон. наук. фахове вид. 2016. № 8.

[10] Малюська В.А., Ціннісні аспекти державного управління в Украӥні//Держава та регіони (Серія: Держ. упр.). 2010. № 4. С. 17-20.

[11] Методологія експертного оиінювання: конспект лекиій/Уклад.: В.П. Новосад, Р.Г. Селіверстов. К: НАДУ, 2008.

[12] Моніторинг та оиінювання стратегій і програм регіонального розвитку в Украӥні / Лендьел М., Винницький Б., Ратейчак Ю., К: В-во «К.І.С.»-2007. 120 с.

[13] Надолішній П.І., Ефективність державного управління та ї оиінювання: концептуальний підхід//Актуал. пробл. держ. упр.: зб. наук. пр. - О: ОРІДУ НАДУ, 2007. Вип. 4. С. 62-76.

[14] Олефіров С., Нормативно-правове забезпечення державно-громадської взаємодї в Украӥні//Актуальні проблеми державного управління : зб. наук. пр. ОРІДУ / [голов. ред. М.М.Іжа]. Вип. 2(70). - Одеса: ОРІДУ НАДУ, 2017, с. 75-79.

[15] Панченко М., Методичні засади оичінки ефективності державного управління соціальною сферою//Актуал. пробл. держ. упр.: зб. наук. пр. - О: ОРІДУ НАДУ, 2007. Вип. 1. С. 61-67.

[16] Пархомчук О., Вимірювання результатів діяльності в суспільному управлінні: зарубіжний досвід//Актуал. пробл. держ. упр.: зб. наук. пр. - Д: ДФ УАДУ. - 2001. Вип. 1.276 с. - С. 147-152. 
[17] Про забезпечення участі громадськості у формуванні та реалізації державної політики: постанова Кабінету Міністрів України від 3 листопада 2010 р. № 996 : [Електронний ресурс] / Режим доступу: www/zakon.rada.gov.ua

[18] Про затвердження Порядку сприяння проведенню громадської експертизи діяльності органів виконавчої влади: постанова Кабінету Міністрів України від 5 листопада 2008 р. № 976: [Електронний ресурс] / Режим доступу: www/zakon.rada.gov.ua

[19] Рудніцька Р.М., Необхідність розвитку аудиту ефективності в Україні та иляхи забезпечення його життєздатності//Реформування системи державного управління та державної служби: теорія і практика: матер. наук.-практ. конф. за міжнар. уч. (22 жовтня 2010 р.): у 2 ч. Ч. 1/за наук. ред. чл.-кор. НАН України В. С. Загорського, доц. А.В. Ліпенцева - Львів: ЛРІДУ НАДУ, 2010. С. 421-425.

[20] Стасишин М., Інституційна спроможність громадянського суспільства в процесі прийняття управлінських рішень//Актуальні проблеми державного управління: зб. наук. пр. ОРІДУ / [голов. ред. М.М.Іжа]. Вип. 1(69). - Одеса: ОРІДУ НАДУ, 2017, C. $129-134$.

[21] Таньчук О.А., Основні підходи до оичінювання ефективності публічного управління//Вісник Національної академії державного управління при Президентові України. 2015. № 3(78), С. 63-70.

[22] Туленков М.В., Теоретико-методологічні основи організаиійної взаємодії сочіальному управлінні: монографія. К: Каравела, 2009. 512 с.

[23] Туронок С.Г., Оиенка государственной политики и задачи реформ: уроки зарубежного опыта / Режим доступа: www.spa.msu.ru/images/File/Vestnik/Turunok. pdf - Название с экрана.

[24] Чебан О.І., Концеептуальні підходи до впровадження та інституціоналізації оцінювання в публічному управлінні// Актуальні пробл. держ. упр.: зб. наук. пр. ОРІДУ / [голов. ред. М.М.Іжа]. Вип. 3(63) - Одеса: ОРІДУ НАДУ, 2015, с. 212-217.

[25] Head B.W., Toward more "evidence-informed" policy making?" Public Administration Review” Vol. 76, Issue 3, May 2016 Pages 472-484.

[26] Cameron John The challenges for monitoring and evaluation in the 1990s - Project Appraisal 8(2) · June 1993 - Taylor \& Francis Pages 91-96.

\section{THE IMPLEMENTATION OF PLURALIST MODEL STATE-ADMINISTRATIVE ACTIVITY IN UKRAINE}

The article is devoted to the existing approaches to the problem of the formation and implementation of evaluation studies of public-administrative activities, emphasized the relevance of the topic the evaluation's use in Ukraine. The development of the conceptual foundations of the modern model of assessing public- administrative activities, defined by us as "pluralistic," is characterized by a high level of synthesis of assessments, a multiplicity of subjects, objects, tasks, methods, tools and evaluation procedures, as well as the wide application of evaluation results and allows obtaining a comprehensive assessment with considering a set of certain criteria. The presented approach is possible for an implementation only if there are several fundamental conditions. The political will is needed to ensure an appropriate level of openness of the authorities and their officials for evaluation procedures. Also, a pluralistic model of evaluation presupposes the existence of a wide range of evaluation subjects ready to cooperate in the implementation of the tasks outlined, with 
appropriate evaluation methods, and with the necessary resources. In addition, there is a need for a public and in-system request for a comprehensive, accurate and objective evaluation of public- administrative activities.

The proposed separation of the conditions for the introduction of pluralistic model of publicadministrative activities' evaluation on the political, organizational, scientific and methodological conditions, the occurrence due to its the estimation will acquire the traits of continuity, consistency and comprehensiveness. Review of political (development of political culture of the society, the political will of the elites), organizational (new place of evaluation in the decision-making structure, an organizational structure for evaluation), scientific and methodological (development of methods and standards of assessment, the presence of the scientific advisory centres) conditions of implementation of evaluation in their specific interdependence allowed the author to draw a conclusion about the leading role of the political preconditions without diminishing the value of others. The implementation of all the above mentioned conditions, possibly in different measure, will introduce a pluralistic model of evaluation of public-administrative activities to obtain a balanced, objective, and full assessments from different subjects of estimation, which are based on many original sources of information and alternative methods of determining the indicators of evaluation.

Keywords: evaluation of public-administrative activities, pluralistic model of evaluation, implementation evaluation of public-administrative activities, terms implementation evaluation.

DOI: 10.7862/rz.2017.mmr.30

Tekst złożono w redakcji: lipiec 2017 r.

Przyjęto do druku: grudzień 2017 r. 
